DOI https://doi.org/10.18551/rjoas.2018-10.01

\title{
FACTORS AFFECTING INDONESIA'S CURRENT ACCOUNT, 1985-2016
}

\author{
Taqwa Edhi* \\ Doctoral Candidate, Doctoral Program of Economics, Postgraduate Program, \\ University of Tadulako, Central Sulawesi, Indonesia \\ Palampanga Anhulaila M., Suparman, Nersiwad \\ Department of Economics and Development Studies, University of Tadulako, \\ Central Sulawesi, Indonesia \\ *E-mail: edhi taqwa@yahoo.com
}

\begin{abstract}
This study aims to test the three hypotheses include the government budget gap, and savings-investment gap that will impact on the current account balance. The government budget deficit will have a significant impact on the current account balance. Similarly, the deficit in savings-investment will have an impact on the current account deficit. Another variable that may affect the current account balance is the exchange rate of the currency. Depreciation of the domestic currency, for example, will be able to affect export volume increase and import volume decrease. The opposite effect on export and import volume will occur if the currency of a country appreciates. The purpose of this research is to know the effect of government budget gap, saving-investment gap, and rupiah exchange rate on current account balance in Indonesia, using annual data from period 1985-2016. This research applies the multiple linear regression approach. The results of this study, both of test (F-test) and partially (t-test), show that the government budget gap, saving-investment gap, and rupiah exchange rate had a positive and significant impact on Indonesia's current account balance during the period 1985-2016.
\end{abstract}

\section{KEY WORDS}

Government budget gap, saving-investment gap, exchange rate, current account balance.

International economic relations will have an effect on the domestic economy. International economic relations occurs because a country has limitation in fulfilling its needs in the form of goods, services and capital. International relations, especially economic relations will be recorded in the balance of payments (BOP). It can be defined as a systematic summary that records the economic transactions of a country that relate to other countries within a certain period of time. Therefore, the BOP of a country basically also shows the performance of international economic relations of a country, which will certainly have an impact on the domestic economy.

International economic relations are of such importance, since today most of the world's economy is an open economy, they export goods and services abroad, import goods and services from abroad, and borrow and lend to world capital markets (Mankiw: 2003: 110 ). Although a country has been able to produce its own goods and services it needs, it is possible to import from another country, when the price of imported goods is cheaper rather than produce in the home country. Therefore, the performance of Indonesia's BOP, especially on the current account balance (CAB) during the period of $1985-2016$ is presented in Appendix 5.

During the period of 1985-2016, the current account developments fluctuated, experiencing a deficit of 2,205 billion rupiahs in 1985 to 46,509 billion rupiahs in 1997, then a surplus in 1988 amounted to 65,757 billion rupiahs and tended to decline to 15,289 billion rupiahs in 2011, then deficit back from 236,132 billion rupiahs in 2012 to 219,638 billion rupiahs in 2016. 
The 1985-1997 period, the current account deficit caused by a surplus in the trade balance (exports and imports of goods) cannot offset the deficit in the balance of services and the balance of income. The service account deficit shows an increasing trend of 1,942 billion rupiahs in 1985 to 70,099 billion rupiahs in 1997. Similarly, the deficit in the income balance, which is the sum of the primary income account and the secondary income account, also showed an increasing trend even though relatively fluctuated from 6,848 billion rupiahs in 1985 to 23,255 billion rupiahs in 1997.

However, the 1985-1997 periods which showed negative performance, during the period of 1998-2011, the current account showed positive performance, although relatively fluctuated from the surplus of 65,757 billion rupiahs in 1998 and tended to decrease to 15,289 billion rupiahs in 2011. Surplus the current account balance, which was affected by a surplus on a relatively large trade balance in all years of observation, was also attributed to a surplus in the income balance in almost all years of observation. In the period of 1998-2011, the income balance experienced only a deficit in 2006-2011 from 80,612 billion rupiahs in 2006 to 203,713 billion rupiahs in 2011.

After experiencing positive performance during the period of 1998-2011, in the next 5 years period (2012-2016) Indonesia's current account balance again showed deficit with fluctuating from 236,132 billion rupiahs in 2012 to 219,638 billion rupiahs in 2016.

During the period of 1985-2016, although Indonesia's current account balance deficit tended to increase but if measured its proportion to Gross Domestic Product (GDP), showed a declining trend, although relatively fluctuated ie from 2.3 percent in 1985 to 1.8 percent on year 2016.

In the future, the trade balance's role is predicted to remain dominant as the main source of improvement in the current account balance, given the role of the balance of services and the balance of income that show more negative performance. The negative performance on the service balance is due to the greater payments of services abroad than the payment of services obtained by Indonesia from abroad. Similarly, the negative performance on the income balance is due to the greater interest payments on foreign loans plus the wages of foreign workers transferred abroad than the interest payments from abroad obtained by Indonesia plus the wages of Indonesian labor transferred from abroad.

Taking into account the trend of annual average growth over the period 1985-2016, where the growth in the service balance, and the income balance larger of the trade balance, ie 13.1 percent for the balance of services; 13.4 percent for the income balance; and 11.8 percent for the trade balance, in the following years the nominal value of Indonesia's current account deficit is predicted to increase.

Based on the background that has been described above, this article entitled "Factors affecting Indonesia, s current account".

\section{LITERATURE REVIEW AND HYPOTHESES}

The current account balance records the flow of trade in goods, services, and unilateral transfers (Salvatore: 1994; Nafziger: 1997). The flow of goods trade includes the export and import of goods. Service trade transactions are transactions for travel and transportation services. Meanwhile, unilateral transfers, among others, include net interest payments on foreign borrowings, and personal transfers in the form of remittances of foreign workers.

Current account performance, whether there will be a deficit or surplus, can be affected by several factors. The following describes several factors that may affect the current account balance.

National Income and Domestic Absorption. National Income is the value of all goods and services produced by a country's population within a certain period. The national income for a mathematically open economy can be written as follows (Batiz: 1994: 266-267):

$$
Y N=C N+I N+G N+X N-M N
$$


Where: $\mathrm{YN}=$ Gross national product $(\mathrm{GNP}), \mathrm{CN}=$ Private consumption expenditure, $\mathrm{IN}=$ Private investment, $\mathrm{GN}=$ Government expenditure, $\mathrm{XN}=$ Export of goods and services, $\mathrm{MN}=$ Import of goods and services.

Since $\mathrm{CN}+\mathrm{IN}+\mathrm{GNis}$ the production of domestic products (domestic absorbtion-AN), where $\mathrm{MN}$ is included, equation (2) becomes:

$$
Y N=(A N-M N)+X N=A N+X N-M N
$$

Where $(\mathrm{XN}-\mathrm{MN})$ is the value of exports of goods and services minus imports of goods and services (net exports).

As indicated above, total domestic spending consists of private consumption (CN), private investment (IN), and government expenditure (GN):

$$
A N=C N+I N+G N
$$

If imports are excluded from domestic expenditures, the remainder is only an expenditure of the population on domestic production:

$$
\mathrm{AN}-\mathrm{MN}=\mathrm{CN}+\mathrm{IN}+\mathrm{GN}-\mathrm{MN}
$$

Hen equation (3) is substituted into equation (2), so as to recover the national income identity equation:

$$
\mathrm{YN}=\mathrm{CN}+\mathrm{IN}+\mathrm{GN}+\mathrm{XN}-\mathrm{MN}
$$

Equation (5) can be rearranged to produce:

$$
\mathrm{XN}-\mathrm{MN}=\mathrm{YN}-\mathrm{AN}
$$

Equation (6) shows the balance of exports of goods and services as a gap between national income and domestic expenditure. This gap is usually referred to as current account balance $(C A B)$ :

$$
\mathrm{CAB}=\mathrm{YN}-\mathrm{AN}
$$

Where: $C A B<0$ means $C A B$ is in a deficit, because to $Y N<A N$ and $X N<M N$; $C A B>0$ means $C A B$ is in surplus, because $Y N>A N$ and $X N>M N ; C A B=0$ means $C A B$ is in balance, because $\mathrm{YN}=\mathrm{AN}$ and $\mathrm{XN}=\mathrm{MN}$.

Savings and Investments. In the national income identity, government expenditure variables (GN) have included investment and consumption expenditures (Batiz: 1994: 268269), thus:

$$
\mathrm{GN}=\mathrm{CNG}+\mathrm{ING}
$$

Where CNG is the government's consumption expenditure, and ING is the government's investment expenditure.

Substituting equation (8) into equation (5), is obtained:

$$
\begin{aligned}
\mathrm{CAB}= & \mathrm{YN}-(\mathrm{CN}+\mathrm{IN}+\mathrm{CNG}+\mathrm{ING})=(\mathrm{YN}-\mathrm{CN}-\mathrm{CNG})-(\mathrm{IN}+\mathrm{ING}) \\
& =\text { gross national savings }- \text { gross national investment } \\
& \mathrm{CAB}=\mathrm{GNS}-\mathrm{GNI}
\end{aligned}
$$

Where gross national savings is equal to the difference between GNP and total consumption (government consumption and private consumption), whereas gross national investment equals domestic investment spending, both private and government. 
In a closed economy, savings and investment should ideally be the same. But in an open economy, savings and investments may not be the same, so national savings can be written:

$$
\mathrm{SN}=\mathrm{YN}-\mathrm{CN}-\mathrm{CNG}
$$

While:

$$
\mathrm{CAB}=\mathrm{XN}-\mathrm{MN}
$$

So that equation (9) can be modified to:

$$
\mathrm{GNS}=\mathrm{GNI}+\mathrm{CAB}
$$

Equation (12) reveals a very important difference between an open and closed economy. In an open economy, saving can be done either by piling up capital reserves or by creating wealth abroad. Whereas in a closed economy savings can be created only by piling up capital reserves.

To correspond with equation (9), equation (12) can be written:

$$
\mathrm{CAB}=\mathrm{GNS}-\mathrm{GNI}
$$

Equation (13) states that the current account balance will have a deficit if the gross national investment exceeds the gross national savings, and vice versa will be a surplus if the gross national investment is less than the gross national savings.

Government Budget Gap and Private Sector Gap. The role of the government sector in the calculation of the current account balance deficit or surplus can be seen through the modification of the right-hand side of equation (2.9), ie by entering corporate taxes and transfer payments. Thus obtained (Batiz: 1994: 274):

$$
C A B=(Y N+T R N-T X N-C N-I N)+(T X N-T R N-G N)
$$

Where $\mathrm{SN}=\mathrm{YN}+\mathrm{TRN}-\mathrm{TXN}-\mathrm{CN}$ indicates the magnitude of private savings, namely the excess of disposible income (YN + TRN - TXN) on private consumption (CN). While (TXN-TRN -GN) shows the excess/lack of government revenue (in this case tax revenues) on government payments (transfers to individuals, and government expenditures).

Equation (14) also states that the current account balance can be related to the gap between private saving and private investment (saving-invesment gap), and/or the gap between domestic tax receipts and transfer payments and government spending (goverment budget gap), or:

$$
C A B=(S N-I N)+(T X N-T R N-G N)
$$

In the gap of the government sector, there will be a budget surplus if positive (TXN> GN + TRN) and a budget deficit if negative (TXN<GN + TRN).

The interpretation of equation (2.15), begins in the event of a private saving and private investment gap and a balance of government revenue and government spending $(T X N=G N+T R N)$. In this case, if the economy faces a current account surplus then the domestic savings will exceed domestic investment with a current account surplus value. This suggests that the excess of domestic savings on domestic investment is invested overseas and shows the net accumulation of assets abroad. The accumulated assets abroad are related to the surplus in $\mathrm{CAB}$. Similar to the above if there is a balance in the government sector, the $C A B$ deficit occurs when there is a relative shortfall in domestic savings compared to domestic investment. To finance the excess investment in savings, the domestic 
population increases the debt to foreign parties in the form of net borrowing or reducing assets abroad.

The next possibility on $C A B$ in equation $(2.15)$ is the government budget deficit, which indicates a shortfall in tax revenues (TXN) on government spending (GN + TRN). If in economy a large private savings equals private investment, $C A B$ will deficit, indicating a deficit in the government budget (TXN<GN + TRN). In this case the government sector borrows abroad to finance the excess of its expenditure on revenues (taxes).

From the above description of the relationship between the government sector finances with the current account balance can be concluded that the deficit government finances (TXN $<G N+T R N$ ) will tend to cause deficit in current account. The current account deficit can be caused by the revenue transferred abroad greater than the income of Indonesia received from abroad. One of the revenue that is transferred abroad is in the form of interest on foreign government loans. The government's foreign borrowing interest is also recorded in the State Budget (APBN) and is one of the contributors to the budget deficit. Thus it can be stated that the current account and the APBN have inseparable linkages.

Currency exchange rate. The foreign exchange rate is the price of one currency measured in another currency (Jamli: 1993). Demand for foreign currency arises from the need to pay for goods and services and assets originating from abroad. Demand and supply of foreign currencies will determine the exchange rate. Increased demand or decreased forein exchange offerings result in a stronger/appreciated exchange rate that will increase the value of the currency. Conversely, declining demand and increased foreign exchange offerings will result in weakening/depreciating exchange rates that will reduce the value of the currency.

Changes in the currency value of a country can also affect the volume of exports and imports due to fluctuation in demand and supply. Depreciation of the domestic currency, for example, will be able to affect export volume increase and import volume decrease. Increased export volume can occur because the price of exported goods (in foreign currency) will become cheaper so that will encourage exports. Meanwhile, the volume of imports will be decreased due to the rise in prices of imported goods (prices in domestic currency). The opposite effect on export and import volume will occur if the currency of a country appreciates.

Previous Research. Merza (2012) has tested the twin deficit hypothesis for Kuwait (1993:4 - 2010:4). The twin deficit hypothesis states an increase in the budget deficit will lead to an increase in current account deficits.

By using the causality test the results show that the direction of causality moves from the current account balance to the balanced budget balance. In this study found a negative long-term relationship between the current account balance with the government's budget balance that is increasing the current account causing a decrease in government budget surplus or an increase in budget deficit.

The findings are in line with Kuwait's economy, as an increase in current account driven mainly by an increase in the trade balance makes central government spend more than it receives in revenues that ultimately leads to a decrease in government budget surplus or an increase in government budget deficits. Therefore, this study concludes that the twin deficit hypothesis is not found for the Kuwaiti case, ie the improved current account balance is not followed by the improved government budget. The government budget becomes a deficit precisely when there is an improvement in the current account balance.

Cavallo (2005) examines the effect of government spending on final goods on the current account balance. The results of the study show that government spending on final goods affects the current account balance more than expected.

The testing of the twin deficit hypothesis has been done also by Tang (2013), using US annual data from 1970 to 2011 period. The result of the study shows that there has been cointegration between balanced budget, current account balance, real income, and interest rate. In addition, the income and the interest rate have a positive and significant impact on the current account. 
Vamvoukas (2015) evaluates the effect of the deficit budget on the current account balance in the Economic and Monetary Union (EMU) countries. This study focuses on testing the validity of twin deficits hypothesis, using data from the period 1970-2008, which is divided into the period 1970-1991 (pre-Maastrict) and 1992-2008 (post-Maastricht). The results show that the impact of the deficit budget on the current account balance in the EMU countries is stronger in the post-Maastricht period than in the pre-Maastricht period. The post-Maastricht period of EMU member states becomes more integrated and has an institution, so that after the Maastricht agreement the government deficit is the main determinant of the current account balance.

Abbassi (2015), conducted a study of the effect of the budget deficit on the current account deficit in Iran from 1981-2012, by arguing the twin deficit hypothesis argument. The results of the study obtained a coefficient of budget deficit of 0.09 indicating that an increase of one unit of budget deficit caused a decrease of 0.09 units in the current account balance. In other words an increase in the budget deficit will lead to an increase in current account deficit.

Akbas (2016) conducted a study to determine the validity of the triple deficit hypothesis, namely: the savings gap, the gap in the budget deficit effect on the current account deficit, using data $\mathrm{G} 7$ countries period 1994- 2011. Findings show that budget deficits and savings gap have an important role in current account deficits in G7 countries.

Namrouty (2015), conducted a study of the effect of public budget deficit on the current account balance in the Palestinian Territories (1996 - 2012). This study aims to determine the exact economic instances that can be used to reduce the current account deficit. The study findings show that there is a positive relationship between the public budget deficit and the current account balance in the Palestinian Territories. It appears that an increase in the public budget deficit of one million US $\$$ will increase the current account deficit by 3.08 million \$.

Puah (2012) examines the twin deficits in developing the economy, using Malaysian economic data, budget deficit data, and current account deficit data, from 1970-2005. The empirical result shows that there is causality in the direction of the current account to the budget deficit variable, ie the worsening of current account deficit can worsen the position of the budget deficit.

Gale (2003), conducts a study of the effects of fiscal policy on related economic variables. The results of the study show: First, the budget deficit will reduce national savings and future national income. Second, fiscal damages have a significant impact on future declines in national income. Third, the expected budget deficit in the future tends to have a significant impact on the expected deficit on long-term bond yields.

Coban (2016) conducted a study on triple deficit theory that is the interaction of government budget deficit, saving-investment deficit, and current account deficit. Using the 24-country transition data for the 2002-2013 period, the results show no evidence of interactions between current account deficits and investment savings deficits, where the investment savings deficit does not lead to current account deficits, current account deficits are caused by factors other than investment saving deficits.

There is an inverse relationship between the fiscal deficit and the current account deficit, ie the improvement of the current accunt deficit will adversely affect the fiscal deficit. This is because indirect taxes from imports have a high contribution to overall tax revenues. When a decline in imports will have an impact on improving current account deficit. However, current account improvements due to the decline in imports will lower the indirect tax revenues from imports and will lower overall tax revenues that will ultimately have an impact on increasing the government budget deficit. Therefore, the decline in imports will have a positive impact on the decrease in current account deficit but on the other hand the decline in imports will have a negative impact on the budget deficit or an increase in government budget deficit.

Palampanga (2017), conducts a study of the domestic resource gap and current account balance in Indonesia, the 2010-2015 period. The results show that private sector gaps, and the government sector, result in deficits in current accounts. 
Iyeli (2017) conducted a study on the budget deficit and current account balance in Nigeria, to investigate the effect of the budget deficit on the current account balance. The study finds that in addition to the inflationary variables that affect the current account balance, the budget deficit, foreign private investment and exchange rate variables have a positive and significant impact on the current account balance.

Erdogan (2014), conducts a fiscal deficit review study with a current account deficit on the Turkish economy. The relationship between the budget deficit and the current account deficit was analyzed for the period 2001Q2-2012Q2. The results show that the budget deficit has a negative and significant effect on the current account balance. On the other hand, the budget deficit has a negative effect on the current account balance in the short run. The review of deficit budgetary relationships with current account deficits centered on the validity of Keynesian views and the Ricardian Equity hypothesis. According to Keynes's view budget deficits will negatively affect the current account balance. In other words the causality relationship of the deficit budget leads to the current account deficit. In contrast to Keynes's view, Ricardian Equality theory supports the idea that in this case there is no relationship between deficit budget and current account deficit.

There are many studies that analyze the interaction between budget deficits and current account deficits. Some studies support the views of Keynes and other studies supporting the theory of Ricardian equality (Erdogan: 2014: 81).

Idil (2010) examines the main determinants of the current account balance in Turkey. This study focuses on the impact of exchange rates, private savings, and government savings on the current account. The exchange rate has a strong impact on the current account. The results of this study also support the twin deficit theory in Turkey.

Odili (2014), examines the impact of the exchange rate on the balance of payments in Nigeria, using the annual data, 1971-2012. The results provide evidence that supports positive and statistically significant relationships in the long run as well as positive but statistically insignificant in the short term between the balance of payments and the exchange rate. The results of further studies reveal that depreciation/devaluation increases the balance of payments. This study recommends policies that will prevent excessive importation and promote export promotion programs based on incentives.

Romelli (2013) examines the impact of trade openness on the relationship between real exchange rates and current account balance, using data from developed and emerging countries from 1970 to 2011. The results show that the improvement in the current account balance is accompanied by a relatively small depreciation of the real exchange rate in a more open economy.

Based on the research question that has been put forward is "How the influence of government budget gap, saving-investment gap, and exchange rate of rupiah against current account balance in Indonesia period 1985-2016" then formulated research hypothesis and statistical hypothesis respectively as follows:

1. The government budget gap has a significant effect on current account, with the statistical hypothesis:

- $\mathrm{HO}: \beta=0$, ie the government budget gap has no significant effect on the current account;

- $\mathrm{H} 1$ : $\beta \# 0$, ie the government budget gap has a significant effect on the current account

2. Saving-investment gap has a significant effect on current account, with statistical hypotheses:

- $\mathrm{HO}: \beta=0$, ie the saving-investment gap has no significant effect on the current account;

- $\mathrm{H} 1: \beta \# 0$, the saving-investment gap has a significant effect on the current account.

3. Exchange rates have significant effect on current account, with statistical hypotheses:

- $\mathrm{HO}: \beta=0$, ie the exchange rate has no significant effect on the current account;

- $H 1: \beta \# 0$, ie the exchange rate has a significant effect on the current account. 


\section{METHODS OF RESEARCH}

Data Types. The writing of this article is based on annual economic data of Indonesia period 1985-2016. The data used are: 1) Current account balance, 2) Government budget gap: which is the difference between total government expenditure and total government revenue (excluding debt receipts), 3) Saving-investment gap: which is the difference between gross national savings with gross national investment. and 4) Rupiah exchange rate (Rupiah/\$ US). The data are sourced from: 1) Statistic YearBook of Indonesia, Indonesian Central Bureau of Statistics, various editions, and 2) Indonesia Balance of Payments Report, Bank Indonesia, various editions.

Multiple Linear Regression. To answer the problems that have been formulated used multiple linier regression analysis method as follows:

$$
C A B=b 0+b 1 G B G+b 2 S I G+b 3 E R C
$$

Where: $\mathrm{CAB}=$ Current account balance (billion rupiah), GBG = Government budget gap (billion rupiah), SIG = Saving-investment gap (billion rupiah), ERC = Exchange rate currency (Rupiah/\$).

The linear regression model has some basic assumptions that must be met to produce a good estimate otherwise known as BLUE (Best Linear Unbiased Estimator). These assumptions include no-multicollinearity, homoscedastic, and no-autocorrelation.

Multicollinearity Test. One of several assumptions on multiple regression models is that there is no definite linear relationship between the independent variables in the model. If there is a definite linear relationship between independent variables then it is stated that the fellow independent variables have occurred collinearity. Multicollinearity means the existence of a perfect or definitive linear relationship, among some or all of the variables describing the regression model (Ajija: 2011: 35, Pindyck: 1998: 95-96). The presence or absence of multicollinearity can be known or seen from the correlation coefficient of each independent variable. If the correlation coefficient between each independent variable is greater than 0.8 then multicollinearity occurs.

Heteroscedasticity Test. Heteroscedasticity is a state in which all the disorders that appear in the population regression function do not have the same variance. Heteroskedasticity test can be done by considering the residual pattern from regression estimation result. If the residual moves constant there is no heteroscedasticity. However, if the residual forms a particular pattern, then it indicates the presence of heteroscedasticity.

Another approach that can be used to identify whether or not heteroscedasticity is comparing $p$-value $\mathrm{Obs}^{*} \mathrm{R}$-Square in heteroscedasticity test with $\partial$ magnitude. If the $p$-value is greater than $\partial$ then there is no heteroscedasticity (Ajija: 2011: 39).

Autocorrelation Test. Autocorrelation indicates the correlation among members of a series of observations that are sequenced according to time and space (Ajija: 2011: 40). So autocorrelation is a correlation between the variables themselves, on different observations of time or individuals. Generally cases of autocorrelation occurs in time series data. Autocorrelation symptoms may indicate a cycle or linear line showing the relationship between ui (residue) as the dependent variable and time as the independent variable (Nachrowi: 2002: 140). According to Ajija (2011: 40) the autocorrelation symptoms can be determined by comparing the values of $\mathrm{F}$ and $\mathrm{Obs}{ }^{*} \mathrm{R}$-Squared, where if the probability value of Obs*R-Squared exceeds the level of trust, then $\mathrm{HO}$ is accepted, meaning there is no autocorrelation problem.

\section{RESULTS AND DISCUSSION}

As described in the analysis method, if the correlation coefficient between each independent variable is greater than 0.8 then multicolinearity occurs.

The correlation values between the independent variables (government budget gaps and saving-investment gaps, government budget gaps and exchange rate, saving-invesment 
gaps and exchange rate) as shown in Appendix 1 all show smaller than 0.8 this means that between those independent variables does not occur multicolinearity. 2011: 39):

Heteroskedasticity test can be done through hypothesis with the following steps (Ajija:

1. HO: no heteroscedasticity;

2. $\mathrm{H} 1$ : there is heteroscedasticity;

3. If $\mathrm{P}$ Value OBS * square $<\alpha$ then $\mathrm{HO}$ is rejected ( $\mathrm{H} 1$ accepted).

Based on Appendix 2 the result of $P$ Value OBS * square is 0.0844 greater than 0.01 or 0.05 , then $\mathrm{H} 0$ is accepted $(\mathrm{H} 1$ is rejected), thus there is no heteroscedasticity in the regression model.

To detect the presence of autocorrelation can be done by testing the autocorrelation hopotesis as follows (Ajija: 2011: 41):

1. HO: there is no serial correlation (serial correlations);

2. $\mathrm{H} 1$ : there is a serial correlation (serial correlations);

3. If $p$ - value Obs * $\mathrm{R}$ - Square $<\alpha$, then $\mathrm{H} 0$ is rejected ( $\mathrm{H} 1$ accepted).

Based on Appendix 3 the result of $P$ Value OBS * square is 0.3142 greater than 0.01 or 0.05 , then $\mathrm{HO}$ is accepted, thus there is no autocorrelation in the research regression model.

Based on the results of multiple regression regarding the factors that affect the current account balance as shown in Appendix 4 then obtained the following regression equation:

$$
C A B=-11,750.83+1.42 \mathrm{GBG}+0.37 \mathrm{SIG}+17.00 \mathrm{ERC}
$$

From equation (4.1) shows a constant value of $-11,750,83$. The value of these constants can be stated that when the government budget gap (GBG), saving-investment gap (SIG) and exchange ratecurrency (ERC) have zero value, the current account deficit is $11,750.83$ billion rupiahs.

The current account deficit shows the greater the value of imports of goods and services than the value of exports. There are still other factors that may affect the current account condition, so even if the GBG, SIG, and ERC values have a zero, the value of the current account may be negative as the regression equation (4.1).

Furthermore, based on the value of each coefficient of independent variables in equation (4.1) can be explained as follows:

Government budget gap variable (GBG) has a regression coefficient value of 1.42 means that if the government budget gap increases by 1 billion rupiahs then the current account balance will increase by 1.42 billion rupiahs.Saving-investment gap variable (SIG) has a regression coefficient value of 0.37 means that if the saving-investmentgap value increases by 1 billion rupiahs then the current account balance will increase by 0.37 billion rupiahs. Rupiah exchange rate variable (ERC) has the value of regression coefficient of 17.00 means if the rupiah exchange rate increases (depreciation) of 1 rupiah then the current account balance will increase by 17.00 billion rupiahs. Based on Appendix 4 which presents the results of multiple regression testing on the factors that affect the current account balance can be explained as follows:

The test of the coefficient of the variable estimator or independent variable is t-test. The independent variable coefficients need to be different from zero significantly or $p$ - value is very small. The test can be done by comparing the value of t-test results statistics on the results of regression with $\mathrm{t}$-table. If the value of $\mathrm{t}$ Statistics $>\mathrm{t}$-table, $\mathrm{HO}$ is rejected and $\mathrm{H} 1$ accepted. In other words there is a significant partial influence of independent variables to dependent variables. Conversely, if the value of $t$ Statistic < t-table $\mathrm{H} 0$ is accepted and $\mathrm{H} 1$ is rejected. In other words partially there is no significant influence of independent variables to dependent variables.

In addition, testing hypothesis can also be done with the concept of $p$-value. This concept is done by comparing $\alpha$ with $p$-value. If the p-value is less than $\alpha$ then $\mathrm{HO}$ is rejected.In this multiple regression analysis using 95\% (a 5\%) confidence level, 1985-2016 observation period (32 years observation number), and there are three independent 
variables (number of parameters, $k=4$ ) then obtained free degree $=28$ so that the t number of two sides is 2.048 .

The results of multiple regression analysis is shown by the level of significance of the influence of each independent variable as follows:

Variable of government budget gap (GBG), at 95\% confidence level ( $\alpha 5 \%$ ), from calculation result obtained $t$ value counted 11.555 . Thus the $t$ value of 11.555 is greater than $\mathrm{t}$ table (11.555> 2.048), so $\mathrm{HO}$ is rejected (Ha accepted). With the receipt of Ha means the government budget gap has a significant effect on the current account balance.

The significant influence of the government budget gap on the current account balance in line with Vamvoukas (2015) which examines the validity of twin deficits hypothesis using EMU countries data from 1970-2008, divided into 1970-1991 (pre Maastrict) and 1992-2008 (post Maastrict). The results show that the impact of the fiscal deficit on the current account balance is stronger in the post-Maastrict period than the pre-Maastrict period.

Similarly Abbasi (2015) using Iranian economic data from 1981-2012, found that an increase in the budget deficit led to an increase in current account deficits. Akbas (2016) conducted a study to determine the validity of triple deficits hypothesis using the data of G7 countries from the period 1994-2011. The results show that the budget deficit, the savings gap, has an important role in the current account deficit. A similar conclusion was generated by Namrouty (2015), using the Palestinian economic data, 1966-2012 period, the result of the study indicates a positive relationship between the public budget deficit and the current account balance. Similarly, lyeli (2017) includes several other independent variables, the budget deficit variable has a positive and significant impact on the current account in Nigeria.

The relationship between the government budget gap and Indonesia's current account balance during the period 1985-2016 can be observed in Appendix 6. Despite the fluctuating developments, the current account deficit during the period of 1985-2016 tended to increase, from the deficit of 2,205 billion rupiahs in 1985, increased to a deficit of 219,638 billion rupiahs in 2016. The level of deficit in the current account was accompanied by an increase in the deficit in the government budget from the deficit of 3,548 billion rupiahs in 1985 to a deficit of 308,340 billion rupiahs in 2016 .

As described in the literature review, current account deficits may be caused by income transferred abroad greater than Indonesian income received from abroad. One of the income that is transferred abroad is in the form of interest on foreign government loans. The government's foreign borrowing interest is also recorded in the state budget of revenues and expenditures (APBN). Thus it can be stated that between the current account balance and the state budget has a closely related.

Variable of saving-investment gap (SIG), at 95\% confidence level (a 5\%), from calculation result obtained $t$ value count equal to 6.744 . Thus the $t$ value of 6.744 is greater than $\mathrm{t}$ table (6.744> 2.048), so $\mathrm{HO}$ is rejected (Ha accepted). With the receipt of Ha means the saving-investment gap has a significant effect on the current account balance.

The significant effect of saving-investment gap on current account balance in line with Akbas (2016) which examines the validity of triple deficits hypothesis by using G7 countries data from 1994 to 2011 period. Government budget gap variables, saving-investment gaps have an important role in the current account deficit.

However, Coban (2016) using data from 24 transition countries for the period 20022013, the results show no evidence of an interaction between current account deficits and saving-investment deficits, where the saving-investment deficit does not cause current account deficits, current account deficits caused by factors other than the deficit of investment savings.

The positive relationship between saving-investment gap and current account deficit on the results of this study is also supported by Batiz (1994: 268-269), through the concept of triple deficits hypothesis as mentioned in the literature review. In addition to being influenced by the government budget deficit, on the concept of triple deficits hypothesis the current account deficit is also caused by the saving-investment gap.

The impact of saving-investment gaps on current account deficits can occur, when a country has an investment requirement greater than the savings that can be provided so that 
the country needs capital flows from abroad. Capital entering a country whether in the form of loan, foreign direct investment (FDI), or portfolio investment will give birth to income that will be transferred abroad. The income is whether the interest of the loan, or the profit from the investment activity will be recorded on the current account of the country. Thus it is clear that the saving-investment deficit will have a negative impact on the current account balance.

The relationship between the saving-investment gap and Indonesia's current account balance during the period 1985-2016 can be observed in Appendix 6. During the period 1985-2016 the saving-investment gap showed an increasing trend although relatively fluctuating ie from the deficit of 13,169 billion rupiahs in 1985 and peaked to a deficit of 648,128 billion rupiahs in 2013 , then decreased again to 1,439 billion rupiahs in 2016 . During that period the deficit also increased in the current account balance from the deficit of 2,205 billion rupiahs in 1985 and peaked to a deficit of 354,883 billion rupiahs in 2013 and continues to decline to a deficit of 219,638 billion rupiahs in 2016 .

The flow of capital into a country that will cover the saving-investment gap has been discussed by Chenery (Jhingan, 2013) with the concept of two gap model in economic development. The rationale is that the gap between saving and investment on the one hand, and the foreign exchange gap on the other hand, becomes an obstacle for non-developed countries in implementing development. Chenery sees foreign aid as a way to close both gaps in achieving targeted economic growth.

Nafziger (1997: 432) states that developing countries derive inflows of capital from abroad when various institutions and individuals from abroad provide assistance or loans or make direct investments to pay for deficits in goods and services on a current account. In 1991, Ghana, for example, received large inflows of capital to pay for trade deficits, service deficits, and reduced liabilities.

Incoming capital from abroad also allows a country to spend more than its production capability, overcome the import export gap, and saving-investment gap. Thus foreign capital will fill the gaps in development activities. Regarding the role of foreign capital in the total investment of developing countries, the World Bank (Nafziger 1997: 433) estimates the role of foreign capital by 10 percent in the 1960s and 20 percent in the 1970s. But the role of foreign capital declined to 8 percent in the 1980s and 12 percent of the 1990s.

According to Strout (cited in Nafziger, 1997), in a model based on the experience of 50 developing countries in 1957-1962, there are three things that limit economic development, 1) skill limitations, 2) saving-investment gaps, 3) disparities the foreign sector (export-import). Skill constraints can be overcome with technology and expertise from abroad. Then for investment and savings constraints, as well as export and import constraints are overcome with the help of foreign capital that can reduce the gap to accelerate growth.

The next discussion for exchange rate variables (ERC), at 95\% confidence level ( $\alpha$ $5 \%$ ), from the calculation results obtained $t$ value counted 6.889 . Thus the $t$ value of 6.889 is greater than t table $(6.889>2.048)$, so $\mathrm{HO}$ is rejected (Ha accepted). With the acceptance of $\mathrm{Ha}$ (along with the positive coefficient of the exchange rate in the regression equation) means that the rupiah exchange rate has a significant and positive effect on the current account balance. The relationship between the rupiah and the current account in the period of 1985-2016 can be seen in Appendix 6.

The significant effect of the rupiah exchange rate (ERC) on the current account balance in line with Idil (2010) which examines the main determinants of the current account balance in Turkey. The exchange rate has a strong impact on the current account.

Similarly Odili (2014), using Nigeria's economic data, the results show that in the long run the exchange rate has a positive and significant impact on the balance of payments. In this study also confirmed that the depreciation will increase the balance of payments.

The effect of the exchange rate on current account balance is reviewed by Romeli (2013). Using the real exchange rate, the results show that, with a relatively small currency depreciation, it will have an impact on improving the current account balance.

$F$ test or model test as a whole is done to see if all the regression coefficients are simultaneously different from zero or accepted model. $F$ test can be done by comparing the test result value ( $F$ statistic) on the regression result with $F$ Table. If the value of $F$ Statistics> 
$\mathrm{F}$ Table then $\mathrm{HO}$ is rejected ( $\mathrm{H} 1$ accepted). In other words, there is a significant relationship between independent variables and dependent variable. Conversely, if the $F$ value of Statistic $<\mathrm{F}$ Table $\mathrm{HO}$ is accepted ( $\mathrm{H} 1$ is rejected). It means that there is no significant influence of independent variables to the dependent variable.

Then, the comparison between the value of $F$ Statistics and $F$ Table hypothesis testing can also be done with the concept of $p$-value. This concept is done by comparing $\alpha$ with $p$ value. If the $\mathrm{p}$-value is less than $\alpha$ then $\mathrm{HO}$ is rejected.

In the multiple regression of factors affecting the current account balance there are 3 (three) independent variables, with the number of observations 32 (Year 1985-2016), with a confidence level of $95 \%$ (a 5\%) then obtained F Table of 2.95.

Based on Appendix 4 obtained $F$ value of Statistics 86.706 which is greater than $F$ Table of 2.95 so that $\mathrm{HO}$ is rejected (accept $\mathrm{H} 1$ ). Thus together all the independent variables are: government budget gap, saving-investment gap, and rupiah exchange rate (ERC) significantly affect the current account balance. Rejection of $\mathrm{HO}(\mathrm{H} 1 \mathrm{receipt})$ is also indicated by the value of Prob (F-Statistic) of 0.000 lower than the a value of $5 \%$.

The next test is the coefficient of determination test (R2). The coefficient of determination shows the ability of the regression line to explain the variation of the dependent variable, namely the variation of the dependent variable which can be explained by the independent variable. The value of $R 2$ ranges from 0 to 1 . The value of $R 2$ is closer to 1 the better the greater the ability of the independent variable to explain the variation of the dependent variable (Ajija: 2011: 34). Similarly Nachrowi (2002: 22), the value of R2 reflects how much variation of the dependent variable can be explained by the independent variable. When $\mathrm{R} 2=0$, it means that the variation of the dependent variable can not at all be explained by the independent variable. Meanwhile when R2 $=1$, meaning the variation of the dependent variable, 100 percent can be explained by the independent variable. The value of $\mathrm{R} 2$ is close to one indicates that there are other variables that influence the dependent variable outside the independent variable already in the model.

The value of R2 also shows how well the regression line describes its data (goodness of fiit). This means whether the regression lines are formed according to the data. If all the data lies on the regression line or in other words all residual values are zero then it has obtained a perfect regression line, however the perfect regression line is rare (Widarjono: 2009: 24). In line with the above definitions, Gujarati (2004: 239), states that the value of R2 will indicate how much the proportion of variation in the dependent variable can be explained by the independent variables simultaneously.

Based on Appendix 4 the value of R2 of 0.902 indicates that the variation in the dependent variable (current account), 90.2 percent can be explained by the independent variables contained in the equation, namely: government budget gap, saving-investment gap, and rupiah exchange rate. Given the relatively large value of R2, this indicates also that the role of other variables outside the independent variables already contained in the regression equation model has a relatively small effect on the current account balance variations.

\section{CONCLUSION AND RECOMMENDATIONS}

Government budget gap variables (GBG) have positive and significant impact on current account balance. This is indicated by the coefficients of government budget gap variables of 1.42; $t$ count value of 11.56; and T table value of 2.048. The variable of savinginvestment gap (SIG) has a positive and significant effect on the current account balance. This is indicated by the saving-investment gap variable of 0.37 ; $\mathrm{t}$ value of 6.74 ; and $\mathrm{T}$ table value of 2.048. The exchange rate variable (ERC) has a positive and significant effect on the current account balance. This is indicated by the rupiah exchange rate variable coefficient of 17.00 ; $t$ value of 6.89 ; and $\mathrm{T}$ table value of 2.048 . Variables of government budget gap, saving-investment gap, and exchange rate of rupiah, together significantly affect the current account balance. This is shown by the value of $F$ Statistics of 86.706 which is greater than $F$ Table of 2.95. The coefficient of determination shown by the value of R2 that is equal to 0.902 . This means that 90.2 percent of the variation in the dependent variable can be 
explained by the independent variables contained in the equation, namely: government budget gap variables, saving-investment gap variables, and exchange rate variables. Given the relatively high value of $\mathrm{R} 2$ then this indicates also that the role of other variables outside the independent variables already contained in the regression equation model has a relatively small effect on the variation of the current account balance variable.

Government budget gaps need to be controlled, among others, by optimizing tax revenue, so it is expected to improve the current account balance position. Savinginvestment gaps need to be reduced by controlling the level of public consumption so that it will have a positive impact on national savings, which in turn is expected to improve the current account position. Decrease/depreciation of the rupiah exchange rate should be controlled at a relatively small level, so that it can have a positive impact on the improvement of current account position.

\section{APPENDIXES}

Appendix 1 - Multicollinearity Test on the Current Account Balance Regression Equation

\begin{tabular}{|c|c|c|c|c|}
\hline & CAB & GBG & SIG & ERC \\
\hline CAB & 1 & 0.796 & 0.661 & -0.347 \\
\hline GBG & 0.796 & 1 & 0.472 & -0.725 \\
\hline SIG & 0.661 & 0.472 & 1 & -0.462 \\
\hline ERC & -0.347 & -0.725 & -0.462 & 1 \\
\hline
\end{tabular}

Source: Appendix 6 (reprocessed).

Appendix 2 - Heteroscedasticity Test on the Current Account Balance Regression Equation

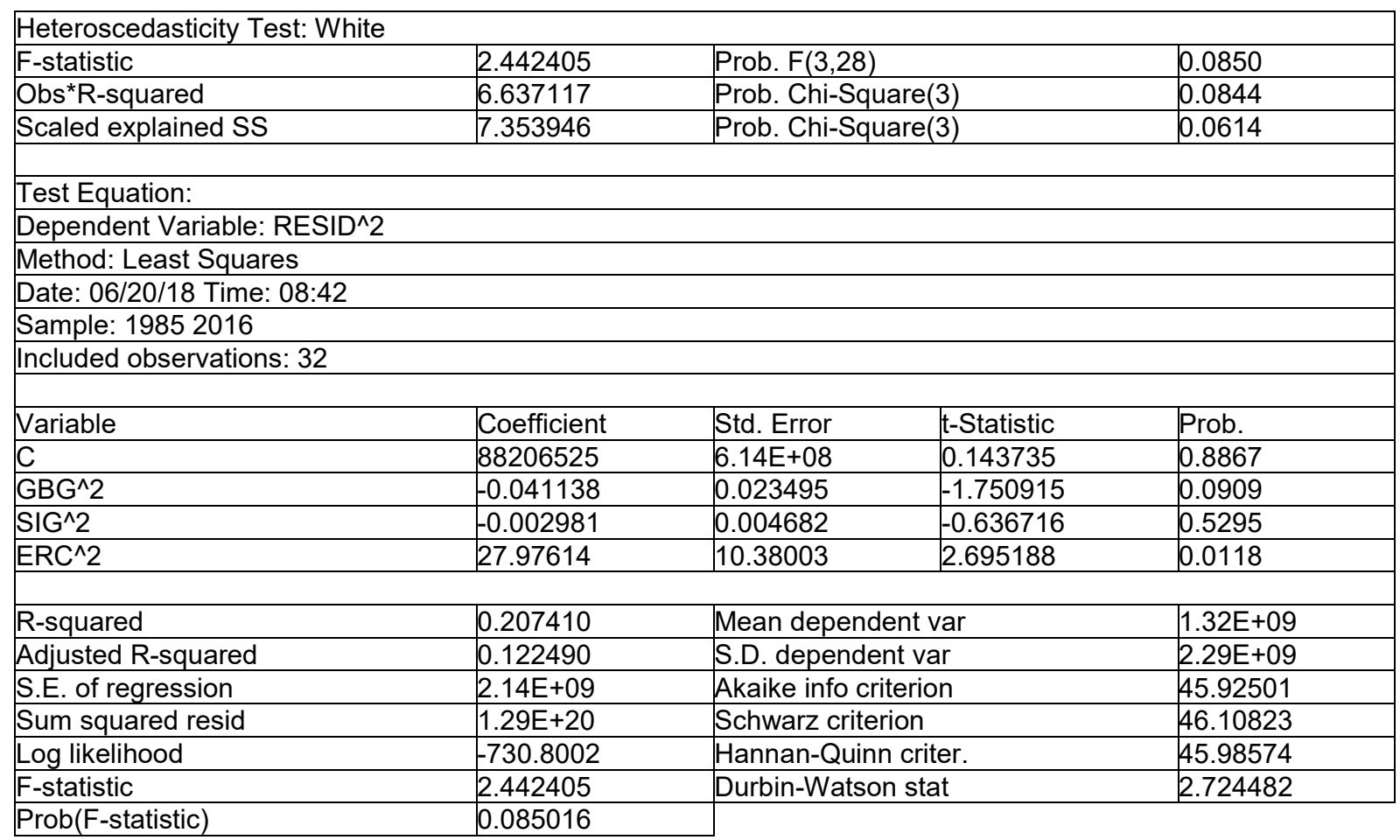

Source: Appendix 6 (reprocessed).

Appendix 3 - Autocorrelation Test on the Current Transaction Balance Regression Equation Breusch-Godfrey Serial Correlation LM Test:

\begin{tabular}{llll} 
F-statistic & 1.014089 & Prob. $F(2,26)$ & 0.3766 \\
Obs*R-squared & 2.315587 & Prob. Chi-Square(2) & 0.3142 \\
\hline
\end{tabular}

Test Equation:

Dependent Variable: RESID 
Appendix 3 Continue

Method: Least Squares

Date: 06/20/18 Time: 08:44

Sample: 19852016

Included observations: 32

Presample missing value lagged residuals set to zero.

\begin{tabular}{lllll}
\hline \hline Variable & Coefficient & Std. Error & t-Statistic & Prob. \\
\hline \hline C & 2947.301 & 14210.39 & 0.207405 & 0.8373 \\
GBG & -0.050916 & 0.128331 & -0.396753 & 0.6948 \\
SIG & 0.052262 & 0.067104 & 0.778821 & 0.4431 \\
ERC & -0.041946 & 2.472197 & -0.016967 & 0.9866 \\
RESID(-1) & 0.256664 & 0.211125 & 1.215697 & 0.2350 \\
RESID(-2) & 0.154688 & 0.213109 & 0.725865 & 0.4744 \\
\hline \hline R-squared & 0.072362 & Mean dependent var & $1.02 E-11$ \\
Adjusted R-squared & -0.106030 & S.D. dependent var & 36959.51 \\
S.E. of regression & 38869.55 & Akaike info criterion & 24.14117 \\
Sum squared resid & $3.93 E+10$ & Schwarz criterion & 24.41600 \\
Log likelihood & -380.2587 & Hannan-Quinn criter. & 24.23227 \\
F-statistic & 0.405636 & Durbin-Watson stat & 2.034796 \\
Prob(F-statistic) & 0.840427 & & \\
\hline \hline
\end{tabular}

Source: Appendix 6 (reprocessed).

Appendix 4 - Result of Current Account Balance Regression

Dependent Variable: CAB

Method: Least Squares

Date: 06/19/18 Time: 23:36

Sample: 19852016

Included observations: 32

\begin{tabular}{|c|c|c|c|c|}
\hline Variable & Coefficient & Std. Error & t-Statistic & Prob. \\
\hline C & -11705.83 & 14064.74 & -0.832282 & 0.4123 \\
\hline GBG & 1.424488 & 0.123276 & 11.55528 & 0.0000 \\
\hline SIG & 0.371658 & 0.055109 & 6.744004 & 0.0000 \\
\hline ERC & 16.99595 & 2.466979 & 6.889377 & 0.0000 \\
\hline R-squared & 0.902818 & \multicolumn{2}{|c|}{ Mean dependent var } & -23881.84 \\
\hline Adjusted R-squared & 0.892405 & \multicolumn{2}{|c|}{ S.D. dependent var } & 118558.5 \\
\hline S.E. of regression & 38889.11 & \multicolumn{2}{|c|}{ Akaike info criterion } & 24.09128 \\
\hline Sum squared resid & $4.23 \mathrm{E}+10$ & \multicolumn{2}{|c|}{ Schwarz criterion } & 24.27450 \\
\hline Log likelihood & -381.4606 & \multicolumn{2}{|c|}{ Hannan-Quinn criter. } & 24.15202 \\
\hline F-statistic & 86.70620 & \multicolumn{2}{|c|}{ Durbin-Watson stat } & 1.585638 \\
\hline
\end{tabular}

Source: Appendix 6 (reprocessed). 
RJOAS, 10(82), October 2018

Appendix 5 - Indonesia Current Account Balance 1985-2006

\begin{tabular}{|c|c|c|c|c|c|c|c|c|c|c|c|c|c|c|}
\hline \multirow{2}{*}{ Number } & \multirow{2}{*}{ Year } & \multirow{2}{*}{$\begin{array}{c}\text { Trade } \\
\text { Balance } \\
\text { (TB) } \\
\text { (Billion } \\
\text { Rupiah) }\end{array}$} & \multirow{2}{*}{$\begin{array}{c}\text { Services } \\
\text { Balance } \\
\text { (SB) } \\
\text { (Billion } \\
\text { Rupiah) }\end{array}$} & \multirow{2}{*}{$\begin{array}{c}\text { Income } \\
\text { Balance } \\
\text { (IB) } \\
\text { (Billion } \\
\text { Rupiah) }\end{array}$} & \multirow{2}{*}{$\begin{array}{c}\text { Current } \\
\text { Account } \\
\text { Balance } \\
\text { (CAB) } \\
\text { (Billion } \\
\text { Rupiah) }\end{array}$} & \multirow{2}{*}{$\begin{array}{c}\text { TB/CAB } \\
\text { (percent) }\end{array}$} & \multirow{2}{*}{$\mathrm{SB} / \mathrm{CAB}$ (percent) } & \multirow{2}{*}{$\begin{array}{c}\text { IB/CAB } \\
\text { (Percent) }\end{array}$} & \multicolumn{2}{|c|}{$\begin{array}{c}\text { Growth of Trade } \\
\text { Balance } \\
\text { (Percent) } \\
\end{array}$} & \multicolumn{2}{|c|}{$\begin{array}{c}\text { Growth ofServices } \\
\text { Balance } \\
\text { (Percent) } \\
\end{array}$} & \multicolumn{2}{|c|}{$\begin{array}{c}\text { Growth oflncome } \\
\text { Balance } \\
\text { (percent) }\end{array}$} \\
\hline & & & & & & & & & Annual & $\begin{array}{c}\text { average } \\
\text { yearly }\end{array}$ & Annual & $\begin{array}{c}\text { average } \\
\text { yearly }\end{array}$ & Annual & $\begin{array}{c}\text { average } \\
\text { yearly }\end{array}$ \\
\hline 1 & 1985 & 6.585 & $(1.942)$ & $(6.848)$ & $(2.205)$ & $(298,6)$ & 88,1 & 310,5 & 7,2 & \multirow{32}{*}{11,8} & $(10,4)$ & \multirow{32}{*}{13,1} & 12,4 & \multirow{32}{*}{13,4} \\
\hline 2 & 1986 & 4.068 & $(2.406)$ & (8.445) & (6.784) & $(60,0)$ & 35,5 & 124,5 & $(38,2)$ & & 23,9 & & 23,3 & \\
\hline 3 & 1987 & 7.427 & $(1.845)$ & $(9.560)$ & $(3.978)$ & $(186,7)$ & 46,4 & 240,3 & 82,6 & & $(23,3)$ & & 13,2 & \\
\hline 4 & 1988 & 9.817 & $(1.869)$ & $(10.632)$ & $(2.683)$ & $(365,9)$ & 69,7 & 396,2 & 32,2 & & 1,3 & & 11,2 & \\
\hline 5 & 1989 & 11.956 & $(14.339)$ & $(2.383)$ & $(4.765)$ & $(250,9)$ & 300,9 & 50,0 & 21,8 & & 667,2 & & $(77,6)$ & \\
\hline 6 & 1990 & 10.174 & $(16.333)$ & (6.159) & $(12.318)$ & $(82,6)$ & 132,6 & 50,0 & $(14,9)$ & & 13,9 & & 158,5 & \\
\hline 7 & 1991 & 9.564 & $(18.312)$ & $(8.749)$ & $(17.498)$ & $(54,7)$ & 104,7 & 50,0 & $(6,0)$ & & 12,1 & & 42,0 & \\
\hline 8 & 1992 & 14.479 & $(20.917)$ & $(6.438)$ & $(12.875)$ & $(112,5)$ & 162,5 & 50,0 & 51,4 & & 14,2 & & $(26,4)$ & \\
\hline 9 & 1993 & 17.367 & $(22.216)$ & $(4.849)$ & $(9.698)$ & $(179,1)$ & 229,1 & 50,0 & 19,9 & & 6,2 & & $(24,7)$ & \\
\hline 10 & 1994 & 17.382 & $(23.894)$ & $(6.512)$ & $(13.024)$ & $(133,5)$ & 183,5 & 50,0 & 0,1 & & 7,6 & & 34,3 & \\
\hline 11 & 1995 & 15.078 & $(30.680)$ & $(15.602)$ & $(31.204)$ & $(48,3)$ & 98,3 & 50,0 & $(13,3)$ & & 28,4 & & 139,6 & \\
\hline 12 & 1996 & 14.174 & $(32.764)$ & $(18.590)$ & $(37.180)$ & $(38,1)$ & 88,1 & 50,0 & $(6,0)$ & & 6,8 & & 19,1 & \\
\hline 13 & 1997 & 46.844 & $(70.099)$ & $(23.255)$ & $(46.509)$ & $(100,7)$ & 150,7 & 50,0 & 230,5 & & 114,0 & & 25,1 & \\
\hline 14 & 1998 & 147.893 & $(115.014)$ & 32.878 & 65.757 & 224,9 & $(174,9)$ & 50,0 & 215,7 & & 64,1 & & $(241,4)$ & \\
\hline 15 & 1999 & 146.551 & $(105.499)$ & 41.052 & 82.104 & 178,5 & $(128,5)$ & 50,0 & $(0,9)$ & & $(8,3)$ & & 24,9 & \\
\hline 16 & 2000 & 240.268 & $(163.595)$ & 76.674 & 153.347 & 156,7 & $(106,7)$ & 50,0 & 63,9 & & 55,1 & & 86,8 & \\
\hline 17 & 2001 & 236.028 & (164.268) & 71.760 & 143.520 & 164,5 & $(114,5)$ & 50,0 & $(1,8)$ & & 0,4 & & $(6,4)$ & \\
\hline 18 & 2002 & 210.197 & $(140.269)$ & 69.929 & 139.857 & 150,3 & $(100,3)$ & 50,0 & $(10,9)$ & & $(14,6)$ & & $(2,6)$ & \\
\hline 19 & 2003 & 207.926 & $(139.300)$ & 68.626 & 137.252 & 151,5 & $(101,5)$ & 50,0 & $(1,1)$ & & $(0,7)$ & & $(1,9)$ & \\
\hline 20 & 2004 & 200.218 & $(171.345)$ & 28.873 & 57.747 & 346,7 & $(296,7)$ & 50,0 & $(3,7)$ & & 23,0 & & $(57,9)$ & \\
\hline 21 & 2005 & 227.781 & (204.838) & 22.943 & 45.886 & 496,4 & $(446,4)$ & 50,0 & 13,8 & & 19,5 & & $(20,5)$ & \\
\hline 22 & 2006 & 267.533 & $(89.190)$ & $(80.612)$ & 97.732 & 273,7 & $(91,3)$ & $(82,5)$ & 17,5 & & $(56,5)$ & & $(451,4)$ & \\
\hline 23 & 2007 & 311.609 & $(104.579)$ & $(103.345)$ & 103.684 & 300,5 & $(100,9)$ & $(99,7)$ & 16,5 & & 17,3 & & 28,2 & \\
\hline 24 & 2008 & 255.234 & (146.007) & (106.116) & 3.110 & $8.207,4$ & $(4.695,1)$ & $(3.412,3)$ & $(18,1)$ & & 39,6 & & 2,7 & \\
\hline 25 & 2009 & 283.382 & $(90.945)$ & (96.623) & 95.814 & 295,8 & $(94,9)$ & $(100,8)$ & 11,0 & & $(37,7)$ & & $(8,9)$ & \\
\hline 26 & 2010 & 279.557 & $(85.334)$ & $(137.634)$ & 56.589 & 494,0 & $(150,8)$ & $(243,2)$ & $(1,3)$ & & $(6,2)$ & & 42,4 & \\
\hline 27 & 2011 & 315.412 & $(96.411)$ & $(203.713)$ & 15.289 & $2.063,0$ & $(630,6)$ & $(1.332,4)$ & 12,8 & & 13,0 & & 48,0 & \\
\hline 28 & 2012 & 83.336 & $(99.901)$ & $(219.567)$ & $(236.132)$ & $(35,3)$ & 42,3 & 93,0 & $(73,6)$ & & 3,6 & & 7,8 & \\
\hline 29 & 2013 & 71.098 & $(147.146)$ & $(278.848)$ & (354.895) & $(20,0)$ & 41,5 & 78,6 & $(14,7)$ & & 47,3 & & 27,0 & \\
\hline 30 & 2014 & 85.861 & $(131.018)$ & $(281.169)$ & $(326.326)$ & $(26,3)$ & 40,1 & 86,2 & 20,8 & & $(11,0)$ & & 0,8 & \\
\hline 31 & 2015 & 193.806 & $(119.975)$ & $(315.505)$ & (241.675) & $(80,2)$ & 49,6 & 130,5 & 125,7 & & $(8,4)$ & & 12,2 & \\
\hline 32 & 2016 & 206.780 & $(87.146)$ & (339.272) & $(219.638)$ & $(94,1)$ & 39,7 & 154,5 & 6,7 & & $(27,4)$ & & 7,5 & \\
\hline
\end{tabular}

Source: 1) Statistic Year Book of Indonesia, Indonesian Central Bureau of Statistics, various editions (reprocessed); 2) Indonesia Balance of Payments Report, Bank Indonesia, various editions (reprocessed). 
Appendix 6 - Current Account Balance, Government Budget Gap, Saving-Investment Gap, and Rupiah Exchange Rate, 1985-2016

\begin{tabular}{|c|c|c|c|c|}
\hline Year & CAB (Billion Rupiah) & GBG (Billion Rupiah) & SIG (Billion Rupiah) & ERC (Rupiah/\$) \\
\hline 1985 & $(2.205)$ & $(3.548)$ & $(13.169)$ & 1.131 \\
\hline 1986 & $(6.784)$ & $(5.206)$ & $(14.551)$ & 1.655 \\
\hline 1987 & $(4.077)$ & $(6.054)$ & $(17.989)$ & 1.652 \\
\hline 1988 & $(2.683)$ & $(9.028)$ & $(25.342)$ & 1.729 \\
\hline 1989 & $(2.383)$ & $(9.565)$ & $(35.568)$ & 1.805 \\
\hline 1990 & $(6.159)$ & $(7.687)$ & $(38.760)$ & 1.992 \\
\hline 1991 & $(8.749)$ & $(8.457)$ & $(37.916)$ & 2.062 \\
\hline 1992 & $(6.438)$ & $(10.262)$ & $(41.910)$ & 2.110 \\
\hline 1993 & $(4.849)$ & $(11.814)$ & $(46.073)$ & 2.200 \\
\hline 1994 & $(6.512)$ & $(11.275)$ & $(61.242)$ & 2.308 \\
\hline 1995 & $(15.602)$ & $(7.395)$ & $(71.163)$ & 2.383 \\
\hline 1996 & $(18.590)$ & $(9.713)$ & $(100.419)$ & 4.650 \\
\hline 1997 & $(23.255)$ & $(20.242)$ & $(100.571)$ & 8.025 \\
\hline 1998 & $(32.878)$ & $(48.056)$ & $(155.053)$ & 7.100 \\
\hline 1999 & 41.052 & $(46.697)$ & $(68.9327)$ & 9.595 \\
\hline 2000 & 76.674 & $(16.000)$ & $(40.721)$ & 10.400 \\
\hline 2001 & 71.760 & $(40.600)$ & $(15.433)$ & 8.940 \\
\hline 2002 & 69.929 & $(23.600)$ & $(101.106)$ & 8.465 \\
\hline 2003 & 68.626 & $(37.600)$ & $(99.404)$ & 9.290 \\
\hline 2004 & 28.873 & $(27.900)$ & $(45.917)$ & 9.830 \\
\hline 2005 & 22.943 & $(14.000)$ & $(85.003)$ & 9.020 \\
\hline 2006 & 97.741 & $(39.984)$ & $(282.736)$ & 9.419 \\
\hline 2007 & 103.694 & $(58.285)$ & $(45.550)$ & 10.950 \\
\hline 2008 & 6.636 & $(60.139)$ & $(69.940)$ & 9.400 \\
\hline 2009 & 95.805 & $(88.634)$ & $(200.044)$ & 8.991 \\
\hline 2010 & 56.589 & $(46.861)$ & $(538.200)$ & 9.068 \\
\hline 2011 & 15.280 & $(84.447)$ & $(648.128)$ & 9.670 \\
\hline 2012 & $(236.122)$ & $(153.093)$ & $(94.694)$ & 12.189 \\
\hline 2013 & $(354.883)$ & $(211.530)$ & $1.439)$ & 12.440 \\
\hline 2014 & $(326.339)$ & $(226.789)$ & $(298.520)$ & 13.795 \\
\hline 2015 & $(241.675)$ & $(308.340)$ & & \\
\hline 2016 & $(219.638)$ & & & \\
\hline
\end{tabular}

Source: 1) Statistic Year Book of Indonesia, Indonesian Central Bureau of Statistics, various editions (reprocessed); 2) Indonesia Balance of Payments Report, Bank Indonesia, various editions (reprocessed). Information: $C A B=$ Current Account Balance, GBG= Government Budget Gap, SIG= Saving-Investment Gap, $E R C=$ Rupiah Exchange Rate.

Appendix 7 - Indonesia Saving-Investment Gap, 1985-2016

\begin{tabular}{|c|c|c|c|c|c|c|}
\hline Year & YN (Billion Rupiah) & $\begin{array}{c}\text { CNG } \\
\text { (Billion } \\
\text { Rupiah) }\end{array}$ & $\begin{array}{c}\text { CN (Billion } \\
\text { Rupiah) }\end{array}$ & $\begin{array}{c}\text { GNS= YN-CN- } \\
\text { CNG(Billion } \\
\text { Rupiah) }\end{array}$ & $\begin{array}{c}\text { GNI= IN+ING } \\
\text { (Billion } \\
\text { Rupiah) }\end{array}$ & $\begin{array}{c}\text { SIG = GNS - } \\
\text { GNI (Billion } \\
\text { Rupiah) }\end{array}$ \\
\hline 1 & 2 & 3 & 4 & 5 & 6 & 7 \\
\hline 1985 & 90.789 & 11.321 & 56.858 & 22.610 & 35.779 & $(13.169)$ \\
\hline 1986 & 91.771 & 12.298 & 60.591 & 18.882 & 33.432 & $(14.551)$ \\
\hline 1987 & 118.522 & 16.214 & 71.989 & 30.319 & 48.308 & $(17.989)$ \\
\hline 1988 & 135.099 & 19.925 & 81.045 & 34.128 & 56.290 & $(22.162)$ \\
\hline 1989 & 159.111 & 23.433 & 88.752 & 46.926 & 72.269 & $(25.343)$ \\
\hline 1990 & 185.982 & 28.581 & 106.312 & 51.088 & 86.656 & $(35.568)$ \\
\hline 1991 & 216.551 & 30.170 & 125.036 & 61.345 & 100.105 & $(38.760)$ \\
\hline 1992 & 247.438 & 33.080 & 135.880 & 78.477 & 116.393 & $(37.916)$ \\
\hline 1993 & 285.849 & 37.607 & 158.343 & 89.899 & 131.809 & $(41.910)$ \\
\hline 1994 & 367.941 & 42.084 & 219.565 & 106.292 & 152.365 & $(46.073)$ \\
\hline 1995 & 441.251 & 48.621 & 279.876 & 112.753 & 173.995 & $(61.242)$ \\
\hline 1996 & 518.921 & 59.530 & 325.585 & 133.806 & 204.969 & $(71.163)$ \\
\hline 1997 & 609.340 & 79.096 & 387.171 & 143.074 & 243.493 & $(100.419)$ \\
\hline 1998 & 901.860 & 131.644 & 647.824 & 122.392 & 222.963 & $(100.571)$ \\
\hline 1999 & 1.031 .083 & 161.992 & 813.183 & 55.908 & 210.960 & $(155.053)$ \\
\hline 2000 & 1.172 .757 & 162.770 & 850.819 & 159.168 & 242.499 & $(83.331)$ \\
\hline 2001 & 1.406 .603 & 204.525 & 972.938 & 229.140 & 298.067 & $(68.927)$ \\
\hline
\end{tabular}




\begin{tabular}{|c|c|c|c|c|c|c|}
\hline 1 & 2 & 3 & 4 & 5 & 6 & 7 \\
\hline 2002 & 1.808 .762 & 194.750 & 1.226 .411 & 387.601 & 428.322 & $(40.721)$ \\
\hline 2003 & 1.936 .261 & 189.400 & 1.186 .723 & 560.138 & 575.571 & $(15.433)$ \\
\hline 2004 & 2.190 .476 & 225.850 & 1.445 .215 & 519.411 & 620.517 & $(101.106)$ \\
\hline 2005 & 2.639 .281 & 259.681 & 1.738 .433 & 641.166 & 740.570 & $(99.404)$ \\
\hline 2006 & 3.196 .948 & 310.644 & 2.022 .819 & 863.485 & 909.402 & $(45.917)$ \\
\hline 2007 & 3.788 .409 & 342.624 & 2.476 .857 & 968.928 & 1.053 .931 & $(85.003)$ \\
\hline 2008 & 4.772 .823 & 505.241 & 3.103 .065 & 1.164 .517 & 1.447 .253 & $(282.736)$ \\
\hline 2009 & 5.409 .984 & 469.529 & 3.174 .205 & 1.766 .250 & 1.811 .800 & $(45.550)$ \\
\hline 2010 & 6.265 .883 & 505.124 & 3.668 .157 & 2.092 .602 & 2.162 .542 & $(69.940)$ \\
\hline 2011 & 7.202 .294 & 648.440 & 4.204 .389 & 2.349 .466 & 2.549 .510 & $(200.044)$ \\
\hline 2012 & 7.986 .246 & 761.513 & 4.765 .448 & 2.459 .285 & 2.997 .485 & $(538.200)$ \\
\hline 2013 & 8.802 .875 & 841.040 & 5.382 .008 & 2.579 .827 & 3.227 .955 & $(648.128)$ \\
\hline 2014 & 10.288 .561 & 924.181 & 5.871 .195 & 3.493 .186 & 3.812 .880 & $(319.694)$ \\
\hline 2015 & 11.210 .427 & 878.740 & 6.301 .328 & 4.030 .359 & 4.124 .603 & $(94.244)$ \\
\hline 2016 & 12.066 .843 & 905.433 & 6.779 .935 & 4.381 .475 & 4.380 .036 & 1.439 \\
\hline
\end{tabular}

Source: Statistic Year Book of Indonesia, Indonesian Central Bureau of Statistics, various editions (reprocessed). Information: $Y N=$ Gross national product, $C N G=$ government's consumption expenditure, $C N=$ Private consumption expenditure, GNS = gross national savings, GNI = gross national investment, IN = Private investment, ING = government's investment expenditure, SIG = Saving-Invesment Gap.

\section{REFERENCES}

1. Abbassi, E., Baseri, B., Alavi, S.S. (2015), The effect of budget deficit on current account deficit: Evidence from Iran, Journal of Economics and Sustainable Development, ISSN 2222-1700 (Paper), Vol.6, No.14

2. Ajija, S. R., Setianto, R. H. (2011), Cara Cerdas Menguasai Eviews, Salemba Empat, Jakarta

3. Akbas, Y. E., Lebe, F. (2016), Current Account Deficit, Budget Deficit and Savings Gap: is The Twin or Triplet Deficit Hypothesis Valid In G7 Countries?, Volume 25, Number 03, Prague Economic Papers.

4. Bank Indonesia, Indonesian Financial-Economy Statistics, Jakarta, various editions.

5. Batiz, F. L. R., Batiz, L.A. R. (1994), International Finance and Open Economy Macroeconomics Second Edition, Macmillan Publishing Company, New York.

6. Cavallo, M. (2005), Government Consumption Expenditures And The Current Account, Working Paper Series,Federal Reserve Bank Of San Francisco.

7. Coban, H., Balikcioglu, E. (2016), Triple Deficit or Twin Divergence : a Dynamic Panel Analysis, The International Journal of Economic and Social Research, Vol. 12, Year 12, No.1, ISSN: $1306-2174$.

8. Erdogan, S. (2014), The Relationship between The Budget Deficit and Current Account Deficit in Turkey, Emerging Market Journal, ISSN2159 - 242X (print) ISSN 2158 -8708 (online), The University Library System of the University of Pittsburgh.

9. Gale, W. G., Orszag, P. R. (2003), Economic Effects of Sustained Budget Deficits, National Tax Journal Vol. LVI, No. 3, Brookings InstitutionWashington, DC 20036.

10. Gujarati, D. N. (2004), Basic Econometrics, Fourth Edition, The McGraw-Hill Companies

11. Idil, U. (2010), Determinants of Current Account: The Relation Between Internal and External Balances in Turkey, Applied Econometrics and International Development Vol. 10-2.

12. Indonesian Central Bureau of Statistics (2015), Statistik 70 Tahun Indonesia Merdeka, Jakarta.

13. Indonesian Central Bureau of Statistics, Statistic Year Book of Indonesia, Jakarta, various editions.

14. Iyeli, I.I., Ovat, O.O. (2015), Budget Deficits and Current Account Disequilibrium in Nigeria: An Econometric Investigation, International Journal of Development and Economic Sustainability, Vol.5, No.4, pp.31-43, Published by European Centre for Research Training and Development UK.

15. Jamli, A. (1993), Dasar-Dasar Keuangan Internasional, BPFE Yogyakarta. 
16. Jhingan, M.L. (2013), Ekonomi Pembangunan dan Perencanaan, PT RajaGrafindo Persada, Jakarta.

17. Merza, E., Alawin, M., Bashayreh, A. (2012, April), The Relationship Between Current Account and Government Budget Balance: The Case of Kuwait, International Journal of Humanities and Social Science, USA.

18. Nachrowi, N. D., Usman, H. (2002), Penggunaan Teknik Ekonometri Pendekatan Populer \& Praktis Dilengkapi Teknik Analisis \& Pengolahan Data Dengan Menggunakan Paket Program SPSS. Jakarta: PT Raja Grafindo Persada.

19. Mankiw, N. G. (2003), Teori Makroekonomi Edisi Kelima, Erlangga, Jakarta.

20. Nafsiger, E.W. (1997), The Economics of Developing Countries, Prentice-Hall,Inc,New Jersey.

21. Namrouty, K. A., Saidam, A. M. (2015), The Effects of Budget Deficit on Current Account: Case Study (Palestinian Territories 1996-2012), International Journal of Economics, Finance and Management Sciences 2015; 3(1): 57-67, ISSN: 2326-9553.

22. Odili, O. (2014), Exchange Rate and Balance of Payment: An Autoregressive Distributed Lag (Ardl) Econometric Investigation on Nigeria, IOSR Journal of Economics and Finance (IOSR-JEF), e-ISSN:2321-5933, p-ISSN: 2321-5925. Volume 4, Issue 6, PP 21-30.

23. Palampanga, A. M., Hasanuddin, B. (2017), The Domestic Resource Gap and Current Transaction Deficit in Indonesia in 2010-2014, Investment Management and Financial Innovations, ISSN Print 1810-4967, ISSN Online 1812-9358, LLC "Consulting Publishing Company "Business Perspectives".

24. Pindyck, R. S., Rubinfeld, D.L. (1998), Econometric Models and Economic Forecasts, Fourth Edition, McGraw-Hill, Singapore.

25. Puah, C. H., Lau, E., Tan, K. L. (2012), Budget-Current Account Deficits Nexus in Malaysia, Munich Personal RePEc Archive, MPRA Paper No.37677.

26. Romeli, D., Terra, C., Vasconcelos, E. (2013), Current Account and Real Exchange Rate changes: the impact of Trade Openness, Universite de Cergy-Pontoise, THEMA.

27. Salvatore, D. (1994), Ekonomi Internasional Edisi Ketiga, Erlangga, Jakarta.

28. Tang, T.C. (2013), Twin Deficits: An Alternative Framework From General Equilibrium Perspective With U.U. Results. Discussion Paper 41/13, Department of Economics, Business and Economics Monash University.

29. Vamvoukas, G. (2015), The effects of Budget Deficits on Current Accounts in the EMU. Investment Management and Financial Innovations, 12(4), LLC "Consulting Publishing Company "Business Perspectives".

30. Widarjono, A. (2009), Ekonometrika Pengantar dan Aplikasinya. Yogyakarta: Penderbit Ekonisia, Fakultas Ekonomi UII. 